\title{
Hubungan ibu bekerja dengan perkembangan balita usia 4-5 tahun di TK Dharma Wanita Desa Grogol Kecamatan Tulangan Kabupaten Sidoarjo
}

\author{
Muntiani', Supartini² \\ 1. Mahasiswa Program Studi D-III Kebidanan Universitas PGRI Adi Buana Surabaya \\ 2. Tenaga Pengajar Program Studi D-III Kebidanan Universitas PGRI Adi Buana Surabaya
}

\begin{abstract}
ABSTRAK
Perkembangan adalah bertambahnya kemampuan (skill) dalam struktur dan fungsi tubuh yang lebih komplek dalam pola yang teratur dan dapat diramalkan, sebagai hasil dari proses kematangan. Faktor-faktor yang mempengaruhi perkembangan anak ada 10, yaitu faktor genetik / herediter faktor lingkungan, nutrisi, lingkungan budaya,keluarga, status sosial dan ekomomi keluarga, iklim / cuaca, olahraga, posisi anak dalam keluarga, status kesehatan,dan faktor hormonal, selain itu ibu juga mempunyai pengaruh besar terhadap perkembangan anak khususnya balita yang usia 4-5 tahun.

Desain penelitian yang digunakan adalah analitik korelasi dengan pendekatan cross sectional. Populasi dalam penelitian ini yaitu seluruh ibu yang bekerja atau ibu yang tidak bekerja yang memiliki balita usia 4-5 tahun di TK Dharma Wanita Desa Grogol Kecamatan Tulangan Kabupaten Sidoarjo dengan sampel 55 orang ibu yang sebagai responden secara random sampling. Intrumen penelitian menggunakan KPSP dan kuesioner sebagai data primer. Dalam penelitian ini variabel independet adalah Ibu bekerja dan variabel dependent adalah perkembangan balita usia 4-5 tahun. Uji statistik yang digunakan adalah uji Chi Square ( $\mathrm{x} 2$ test) dengan $\alpha=0,05$ dan diperoleh perhitungan chi quadrat lebih besar dari pada tabel $(10,3>5,99)$ dengan signifikasi $p=0,000<\alpha$.

Hasil penelitian perkembangan balita usia 4-5 tahun dengan asuhan ibu bekerja sebanyak 24 balita $(68,6 \%)$ perkembangannya meragukan, sebanyak 2 balita $(5,7 \%)$ perkembangannya penyimpangan dan sebanyak 9 balita $(25,7 \%)$ perkembangan sesuai. Perkembangan balita usia 45 tahun dengan asuhan ibu tidak bekerja sebanyak 5 balita $(25,0 \%)$ perkembangannya meragukan, sebanyak 1 balita $(5,0 \%)$ perkembangannya penyimpangan dan sebanyak 14 balita $(70,0 \%)$ perkembangan sesuai.

Saran yang diberikan bagi para petugas kesehatan dan para ibu baik yang bekerja dan tidak bekerja untuk selalu memantau perkembangan anaknya dengan selalu memberikan rangsangan serta kualitas interaksi dengan anak agar ibu mengetahui bagaimana perkambangan anaknya.
\end{abstract}

Kata kunci : Ibu bekerja, perkembangan balita usia 4-5 tahun

\section{PENDAHULUAN}

Perempuan merupakan sumber daya manusia, sama dengan kaum laki-laki. Ini berarti bahwa kaum perempuan juga memperoleh kesempatan yang sama dengan kaum laki-laki, untuk mengembangkan kemampuan, pengetahuan dan keterampilannya sesuai dengan bakatnya, dan kemudian mempergunakannya dengan memperoleh upah yang layak guna membantu peningkatan taraf hidup keluarganya (KS. Keswara,1998:11).

Anak adalah potensi dan penerus cita-cita bangsa, yang dasarnya telah diletakkan oleh generasi sebelumnya. Jika anak dipupuk dan dipelihara dengan baik, maka anak akan berkembang dengan baik pula sesuai dengan keinginan dan harapan. Akan tetapi bila anak tidak dipupuk dan tidak dipelihara atau dirawat dengan baik, maka jelas anak tidak akan berkembang sebagaimana mestinya. Kita sering mendengar dan bahkan melihat bahwa anak sering diperlakukan tidak adil dan kurang wajar, sehingga kemungkinan anak berperilaku kurang ajar, disisi lain anak dituntut untuk menjadi generasi penerus keluarga dan bahkan bangsa yang berkualitas, namun tidak sedikit keluarga yang mengabaikan hak-hak anak (Drs.Suherman, 2012:5).

Jumlah Balita di Indonesia sekitar 10\% dari seluruh populasi. Sebagai calon generasi penerus bangsa, kualitas tumbuh kembang balita di Indonesia perlu mendapat perhatian serius. pertumbuhan 
perkembangan anak secara komperhensip dan berkualitas yang diselenggarakan melalui kegiatan stimulasi, deteksi dan intervensi dini penyimpangan pertumbuhan perkembangan balita dilakukan pada "masa kritis " (Dep Kes RI, 2008:1).

Namun demikian ternyata tidak semua balita dapat berkembang seperti yang seharusnya, terkadang ada balita yang lambat atau bahkan tidak dapat melakukan kemampuan yang seharusnya dimiliki pada tahapan usianya, kondisi seperti ini kadang sangat tidak difahami oleh para orang tua, biasanya orang tua baru menyadari setelah segalanya sudah terlambat, oleh sebab itu pengetahuan dan pemahaman tentang perkembangan balita harus sudah dimiliki orang tua sejak balita tersebut masih dalam usia dini.http://bayidananak.com/

Berdasarkan data dari Dinas Kesehatan tingkat I Propinsi Jawa Timur 2011 untuk deteksi tumbuh kembang balita di Jawa Timur di tetapkan $80 \%$ namun cakupan balita yang di diperiksa sebanyak $40-59 \%$ dan yang mengalami perkembangan tidak optimal sebanyak 0,14\%. (Dep Kes RI, 2008:1).

Banyak faktor- faktor yang mempengaruhi perkembangan anak antara lain: faktor genetik merupakan faktor yang dapat diturunkan sebagai dasar dalam mencapai hasil akhir proses perkembangan anak, faktor lingkungan merupakan faktor yang sangat penting dalam menentukan tercapai atau tidaknya potensi yang telah dimiliki oleh anak, faktor internal merupakan faktor yang dimiliki anak tersebut misalnya IQ,pengaruh hormonal, pengaruh emosi.(Ai yeyeh rukiyah,2012, 108)

Data yang diperoleh di Polindes Desa Grogol Kecamatan Tulangan Kabupaten Sidoarjo, petugas kesehatan melakukan pengamatan terhadap 10 balita usia 4-5 tahun dengan memberi permainan memasang baju boneka lompat dengan satu kaki dan mengancingkan baju sendiri didapat hasil 6 balita $60 \%$ dengan ibu yang dirumah tidak dapat mengancingkan baju sendiri, balita dapat mengancingkan bajunya sendiri di dapatkan 4 balita $40 \%$ dengan ibu yang bekerja. Dari kejadian tersebut peneliti ingin mengetahui hubungan ibu bekerja dengan perkembangan balita usia 4-5 tahun di TK Dharma Wanita Desa Grogol Kecamatan Tulangan kabupaten Sidoarjo.

Berdasarkan latar belakang yang telah diuraikan, disusun suatu rumusan masalah sebagai berikut "Adakah hubungan antara ibu bekerja dengan perkembangan anak usia 4-5 tahun diTK Dharma Wanita Grogol Kecamatan Tulangan Kabupaten Sidoarjo ?".

Tujuan umum penilitian ini adalah untuk mengetahui hubungan antara ibu bekerja dengan perkembangan anak usia 4-5 tahun diTK Dharma Wanita Grogol Kecamatan Tulangan Kabupaten Sidoarjo. Tujuan khusus nya adalah 1.) Mengidentifikasi ibu bekerja yang mempunyai balita yang usia 4-5 tahun di TK Dharma Wanita grogol Kecamatan Tulangan Kabupaten Sidoarjo; 2.) Mengidentifikasi perkembangan anak usia 4-5 tahun di TK Dharma Wanita grogol Kecamatan Tulangan Kabupaten Sidoarjo; 3.) Menganalisis hubungan perkembangan balita usia 4-5 tahun dengan asuhan ibu bekerja di TK Dharma Wanita grogol Kecamatan Tulangan Kabupaten Sidoarjo.

Manfaat Penelitian ini bagi peneliti adalah 1.) Agar peneliti memperoleh pengalaman tentang hubungan ibu bekerja dengan perkembangan balita usia 4-5 tahun di TK Dharma Wanita Grogol Kecamatan Tulangan Kabupaten Sidoarjo; 2.) Mendapatkan informasi tentang hubungan ibu bekerja dengan perkembangan balita usia 4-5 tahun di TK Dharma Wanita Grogol Kecamatan Tulangan Kabupaten Sidoarjo. Bagi Masyarakat Umum, yaitu sebagai bahan informasi dalam meningkatkan pengetahuan terhadap perkembangan balita dengan pola asuh ibu yang bekerja di TK Dharma Wanita Grogol Kecamatan Tulangan Kabupaten Sidoarjo. Bagi Institusi Pendidikan, adalah : 1.) Sebagai bahan referensi atau data dasar perkembangan ilmu pengetahuan khususnya tentang tingkat kemandirian balita di TK Dharma Wanita Grogol Kecamatan Tulangan Kabupaten Sidoarjo; 2.) Sebagai bahan masukan untuk penelitian selanjutnya. Bagi tempat penelitian, diharapkan hasil penelitian dapat memberikan bahan masukan dalam rangka memberi pengetahuan tentang hubungan ibu bekerja dengan perkembangan balita anak usia 4-5 tahun di TK Dharma Wanita Grogol Kecamatan Tulangan Kabupaten Sidoarjo.

\section{BAHAN DAN METODE}

Desain penelitian merupakan suatu strategi untuk mencapai tujuan penelitian yang ditetapkan dan berperan sebagai pedoman peneliti pada seluruh proses penelitian (Nursalam, 2008). Dalam penelitian ini rancang 
bangun yang dipakai adalah metode penelitian analitik dan secara garis besar metode penelitian analitik dibagi menjadi 3 yaitu cross sectional,case control (retrospective), cohort. Penelitian ini memakai cross sectional dimana melakukan observasi atau pengukuran variabel sesaat, artinya subyek diobservasi satu kali saja dan pengukuran variabel independent dan

dependent dilakukan pada saat pengkajian atau pemeriksaan data (Soekidjo,2010:37).

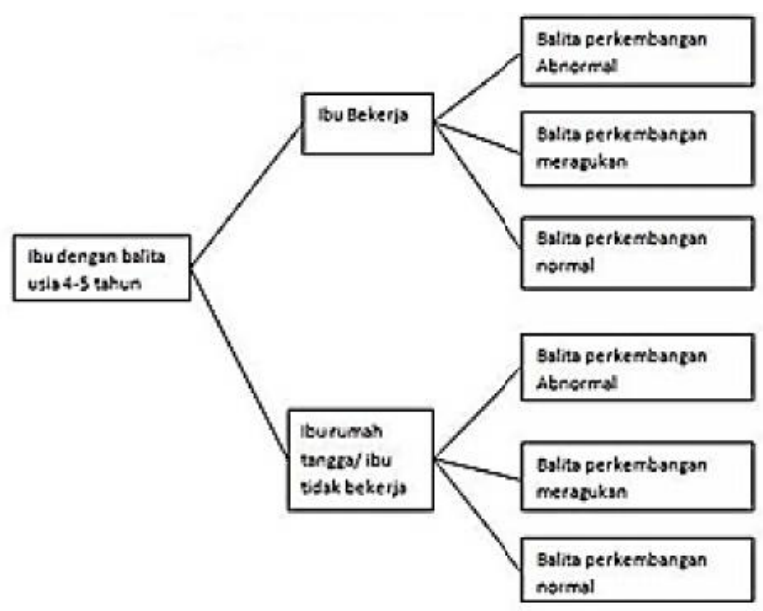

Gambar 1 - Desain Penilitian

Waktu penelitian adalah dimulai FebruariJuni 2013 dan waktu pengambilan data pada bulan April 2013. Penelitian ini dilakukan di TK Dharma Wanita Desa Grogol Kecamatan Tulangan Kabupaten Sidoarjo.

Populasi dalam penelitian ini yaitu seluruh Ibu dan balita usia 4-5 tahun di TK Dharma Wanita Grogol Kecamatan Tulangan Kabupaten Sidoarjo, pada tahun ajaran 20122013 dengan $N=64$. Sampel dalam penelitian ini adalah sebagian ibu dan balita usia 4-5 tahun di TK Dharma Wanita Grogol Kecamatan
Tulangan Kabupaten Sidoarjo pada tahun ajaran 2012-2013 dengan besar sempel $n=55$.

Supaya memperoleh besar sampel yang proposional dihitung dengan menggunakan rumus dibawah ini : (Nursalam, 2003).

\section{Keterangan :}

$\mathrm{N}$ : Besar populasi

$\mathrm{n}$ : Besar sampel

d : Tingkat kepercayaan atau ketetapan yang diinginkan $(0,05)$

Diketahui : $\mathrm{N}=64 \mathrm{~d}=0,05$

Ditanya $: \mathrm{n}=\ldots \ldots$ ?

Dijawab :

$$
=55
$$

Pengambilan sampel penelitian ini menggunakan teknik Simple Random Sampling yaitu setiap anggota atau unit dari populasi mempunyai kesempatan yang sama untuk diseleksi sebagai sampel (Soekidjo Notoatmodjo, 2010:120). Untuk mencapai sampling ini balita diseleksi secara acak dan diperoleh $\mathrm{n}=55$ sampel.

Sebagai variabel independent dalam penelitian ini adalah ibu bekerja, sedangkan variabel dependent dalam penelitian ini adalah perkembangan balita usia 4-5 tahun.

Instrumen yang digunakan pada penelitian ini adalah dengan menyebarkan KPSP dan kuesioner dengan menggunakan alat bantu berupa pencil, kertas, kubus warna-warni, dll. Pada ibu balita di TK Dharma Wanita Desa Grogol Kecamatan Tulangan Kabupaten Sidoarjo, teknik pengumpulan data dilakukan oleh peneliti dibantu bidan desa dan guru TK untuk menyebarkan wawancara sesuai kuesioner dan formulir KPSP.

Data yang terkumpul diolah dengan menggunakan tabel distribusi frekuensi yang dikonfirmasikan dalam bentuk persen dan diberi narasi kemudian dilakukan uji statistik. Untuk mengetahui hubungan lbu bekerja dengan perkembangan usia 4-5 tahun di TK Dharma Wanita Grogol, dilakukan analisis yaitu dengan menggunakan uji Chisquare (x2).

Data kemudian disajikan dalam bentuk tabulasi silang (tabel $2 \times 3$ ) dengan kriteria penelitian : jika $X^{2}$ hitung lebih besar dari $X^{2}$ tabel maka $\mathrm{HO}$ (hipotesis nol) ditolak dengan taraf signifikasi $\alpha=0,05$, artinya ada perbedaan perkembangan balita usia 4-5 tahun antara ibu bekerja dan tidak bekerja. Penyajian hasil penelitian disajikan dalam bentuk tabel dengan kriteria:

1. Sebagian kecil $=0 \%-25 \%$ 


$\begin{array}{lll}\text { 2. } & \text { Hampir setengah } & =26 \%-49 \% \\ \text { 3. } & \text { Setengahnya } & =50 \% \\ \text { 4. } & \text { Lebih dari setengah } & =51 \%-75 \% \\ \text { 5. } & \text { Sebagian besar } & =76 \%-99 \% \\ & \text { Seluruhnya } & =100 \%\end{array}$

\section{HASIL DAN PEMBAHASAN}

Berikut ini akan disajikan data hasil penelitian yang berjudul hubungan ibu bekerja dengan perkembangan balita usia 4-5 tahun di TK Dharma Wanita Desa Grogol Kecamatan Tulangan Kabupaten Sidoarjo. Secara jelas hasil penelitian ini akan di sajikan hasil pengumpulan data yang di peroleh dari hasil pengisian KPSP pada balita dan kuesioner pada ibu yang dilakukan pada 24-25 mei 2013 di TK Dharma Wanita Desa Grogol Kecamatan Tulangan Kabupaten Sidoarjo, didapatkan data umum dan data khusus.

\section{Data Umum}

\begin{tabular}{llll}
\hline Kriteria umur & $F$ & $\%$ & \\
\hline $20-30$ tahun 27 & 49 & \\
$>30$ tahun & & 28 & 51 \\
\hline Jumlah & 55 & 100 &
\end{tabular}

Tabel 1 - Umur Ibu Balita Di TK dharma Wanita Desa Grogol Kecamatan Tulangan Kabupaten Sidoarjo pada tanggal 24 Mei 2013

Berdasarkan tabel 1 menunjukan bahwa dari 55 ibu sebagian besar (51\%) berusia > 30 tahun.

\begin{tabular}{lll}
\hline Kreteria Pendidikan & $\mathrm{F}$ & $\%$ \\
\hline Dasar (SD dan SMP) & 18 & 22,7 \\
Menengah (SMA) & 24 & 43,6 \\
Perguruan tinggi (D3 / SARJANA) & 13 & 23,7 \\
\hline Jumlah & 55 & 100 \\
\hline
\end{tabular}

Tabel 2 - Pendidikan Ibu Balita Di TK dharma Wanita Desa Grogol Kecamatan Tulangan Kabupaten Sidoarjo pada tanggal 24 Mei 2013

Berdasarkan tabel 2 menunjukan bahwa dari 55 ibu hampir setengahnya (43,6\%) berpendidikan SMA.

\begin{tabular}{lll}
\hline Umur Balita & $\mathrm{F}$ & $\%$ \\
\hline Umur 4 Tahun & 19 & 34,5 \\
Umur 4 1/2 Tahun & 15 & 27,2 \\
5 Tahun & 21 & 38,3 \\
\hline Jumlah & 55 & 100
\end{tabular}

Tabel 3 - Umur Balita Di TK dharma Wanita Desa Grogol Kecamatan Tulangan Kabupaten Sidoarjo pada tanggal 24 Mei 2013
Berdasarkan tabel 3 menunjukan bahwa hampir setengahnya (38,3\%) berusia 5 tahun.

\section{Data Khusus}

\begin{tabular}{lll}
\hline Perkerjaan & $\mathrm{F}$ & $\%$ \\
\hline Tidak bekerja & 20 & 36,4 \\
Bekerja & 35 & 63,6 \\
\hline Jumlah & 55 & 100 \\
\hline
\end{tabular}

Tabel 4 - Pekerjaan Ibu Balita di TK Dharma Wanita Desa Grogol Kecamatan Tulangan Kabupaten Sidoarjo pada tanggal 24 Mei 2013

Berdasarkan tabel 4 menunjukanbahwa sebagian besar $(63,6 \%)$ ibu yang bekerja.

\begin{tabular}{lll}
\hline $\begin{array}{l}\text { Perkembangan Balita } \\
\text { Usia 4-5 Tahun }\end{array}$ & $\mathrm{F}$ & $\%$ \\
\hline Penyimpangan & 3 & 5,5 \\
Meragukan & 29 & 52,7 \\
Sesuai & 23 & 41,8 \\
\hline Jumlah & 55 & 100 \\
\hline
\end{tabular}

Tabel 5 - Perkembangan balita usia 4-5 tahun di TK Dharma Wanita Desa Grogol Kecamatan Tulangan Kabupaten Sidoarjo pada tanggal 24 Mei 2013

Berdasarkan tabel 5 menunjukan bahwa sebagian besar balita usia 4-5 tahun, 29 balita $(52,7 \%)$ perkembangannya meragukan.

Pekerjaan IbuPerkembangan Balita Usia 4-5 TahunTotal

\begin{tabular}{lccccc}
\hline \multicolumn{5}{c}{ Penyimpangan } & \multicolumn{3}{c}{ Meragukan Sesuai } \\
\hline \multicolumn{1}{c}{$\mathrm{N}$} & $\%$ & $\mathrm{~N}$ & $\mathrm{~N}$ & $\%$ & $\mathrm{~N} \%$ \\
\hline Tidak Bekerja & 1 & $5 \%$ & 5 & $25 \%$ & $1470 \% 20100 \%$ \\
Bekerja & 2 & $5,7 \%$ & $2468,8 \% 925,7 \% 35100 \%$ \\
Total & $35,5 \%$ & $2952,7 \% 2341,8 \% 55100 \%$ \\
\hline \multicolumn{5}{c}{$\alpha=0,05$} & $\mathrm{p}=0,000$ \\
\hline
\end{tabular}
perkembangan balita usia 4-5 tahun Di TK Dharma Wanita Desa Grogol Kecamatan Tulangan Kabupaten Sidoarjo pada tanggal 24 Mei 2013

Berdasarkan tabel 6 menunjukan dari 35 ibu yang bekerja sebagian besar (68,6\%) mempunyai balita yang meragukan sedangkan dari 20 ibu yang tidak bekerja sebagian besar $(70,0 \%)$ mempunyai balita yang sesuai. Hasil pengujian statistik dengan menggunakan uji Chi Square ( $\mathrm{x} 2$ test) menunjukan adanya nilai probabilitas 0,000 yang berarti lebih kecil dari $\alpha$ $=0,05$. Ketentuan pengujian kalau harga chi quadrat dihitung lebih besar atau sama dengan tabel maka hubungannya signifikan. Dari perhitungan diatas ternyata chi quadrat lebih besar dari pada tabel $(10,3>5,99)$ dengan 
demikian disimpulkan ada hubungan ibu bekerja dengan perkembangan balita usia 4-5 tahun di Desa Grogol Kecamatan Tulangan Kabupaten Sidoarjo.Ibu Tidak bekerja dan Bekerja di TK Dharma Wanita Desa Grogol Kecamatan Tulangan Kabupaten Sidoarjo.

Berdasarkan hasil penelitian didapatkan bahwa $35(63,6 \%)$ ibu balita yang bekerja .Menurut teori Lemer (2008) )lbu bekerja adalah seorang ibu yang bekerja diluar rumah untuk mendapatkan penghasilan disamping membesarkan dan mengurus anak dirumah. ibu bekerja adalah ibu yang memiliki anak dari umur 0-18 tahun dan menjadi tenaga kerja. Menurut KS. Keswara (1998), perempuan merupakan sumber daya manusia, sama dengan kaum laki-laki. Ini berarti bahwa kaum perempuan juga memperoleh kesempatan yang sama dengan kaum laki-laki, untuk mengembangkan kemampuan, pengetahuan dan keterampilannya sesuai dengan bakatnya, dan kemudian mempergunakannya dengan memperoleh upah yang layak guna membantu peningkatan taraf hidup keluarganya.

lbu yang bekerja paruh waktu berbeda dengan ibu yang bekerja sehari penuh. Ibu yang bekerja paruh waktu masih bisa meluangkan waktunya untuk mengasuh balitanya dengan baik.Perkembangan balita usia 4-5 tahun di TK Dharma Wanita Desa Grogol Kecamatan Tulangan Kabupaten Sidoarjo

Berdasarkan tabel 5 diatas terlihat bahwa perkembangan balita usia 4-5 tahun 29 balita $(52,7 \%)$. Faktor-faktor yang mempengaruhi menurut teori Marlow, 1988 dalam Supartini,2004 Faktor herediter : merupakan faktor pertumbuhan yang dapat diturunkan yaitu suku, ras, dan jenis kelamin (Marlow, 1988 dalam supartini,2004). Jenis kelamin ditentukan sejak dalam kandungan.Faktor lingkungan : lingkungan pranatal, kondisi lingkungan yang mempengaruhi fetus dalam uterus yang dapat mengganggu pertumbuhan dan perkembangan janin antara lain gangguan nutrisi karena ibu kurang mendapatkan asupan nutrisi yang baik.Nutrisi, adalah salah satu komponen yang penting dalam menunjang keberlangsungan proses pertumbuhan dan perkembangan. Lingkungan budaya, budaya keluarga atau masyarakat akan mempengaruhi bagaimana mereka dalam mempersepsikan dan memahami kesehatan dan prilaku hidup sehat, misal: pekerjaan/ pendapatan keluarga, pendidikan ayah/ ibu, jumlah saudara/ jenis kelamin dalam keluarga, stabilitas dalam keluarga, kepribadian ayah dan ibu, adat istiadat, norma-norma dalam keluarga, agama dan kehidupan politik dalam keluarga. (Soetjiningsih,1995:10). Status sosial dan ekonomi keluarga, anak yang dibesarkan di keluarga yang berekonomi tinggi untuk pemenuhan kebutuhan gizi akan tercukupi dengan baik dibandingkan dengan anak yang dibesarkan dikeluarga perekonomian sedang dan kurang olahraga atau latihan saat fisik yang teratur: iklim / cuaca, iklim tertentu akan mempengaruhi status kesehatan anak misalnya musim penghujan akan dapat menimbulkan banjir sehingga menyebabkan sulitnya transportasi untuk mendapatkan bahan makanan, timbul penyakit menular, dan penyakit kulit yang dapat menyerang bayi dan anak-anak. Olahraga / latihan fisik, manfaat olahraga atau latihan fisik yang teratur akan meningkatkan sirkulasi darah sehingga meningkatkan suplai oksigen keseluruh tubuh, meningkatkan aktifitas fisik dan menstimulasi perkembangan otot dan jaringan sel.Posisi anak dalam keluarga, posisi anak sebagai anak tunggal, anak sulung, anak tengah atau anak bungsu akan mempengaruhi pola perkembangan anak tersebut diasuh dan didik dalam keluarga. Status kesehatan, status kesehatan anak dapat berpengaruh pada pencapaian pertumbuhan dan perkembangan. Faktor hormonal, faktor hormonal yang berperan dalam pertumbuhan dan perkembangan anak adalah somatotropon yang berperan dalam mempengaruhi pertumbuhan tinggi badan, hormon tiroid dengan menstimulasi metabolisme tubuh. (Ai yeyeh rukiyah, 2012,108).

Setiap balita perkembangan berbeda- beda dan ini dipengaruhi banyak faktor, oleh sebab itu sebagai orang tua harus bisa memahami tentang perkembangan supaya balitanya berkembang secara optimal.

Hubungan ibu bekerja dengan perkembangan balita usia 4-5 tahun Di TK Dharma Wanita Desa Grogol Kecamatan Tulangan Kabupaten Sidoarjo

Analisa hasil penelitian menunjukan ada hubungan ibu bekerja dengan perkembangan balita usia 4-5 tahun di TK Dharma Wanita Desa Grogol Kecamatan Tulangan Kabupaten Sidoarjo, dimana dari 35 ibu yang bekerja sebagian besar 24 (68,6\%) mempunyai balita yang meragukan, hal ini sesuai dengan teori Emmy (1986) perkembangan dapat terpenuhi 
secara optimal. Namun jika kasih sayang dan perkembangan anak menjadi terganggu akibat intraksi ibu dengan anak sangat terbatas, maka perlu pemikiran lebih mendalam sebelum memutuskan untuk bekerja. Jika perhatian, kasih sayang serta stimulasi perkembangan terhadap anak tetap dapat diberikan meskipun ibu bekerja, maka sebenarnya apa yang dilakukan seorang ibu adalah perbuatan yang sangat mulia, karena ibu telah berperan aktif dalam membantu perekonomian keluarga disamping tugas utamanya sebagai seorang ibu. Seorang ibu yang tidak bekerjapun belum tentu dapat memberikan kasih sayang dan melakukan stimulasi perkembangan pada anak dengan baik . Interaksi ibu dengan anak juga sangat ditentukan oleh seberapa berkualitasnya kebersamaan yang terjalin diantara mereka. Ibu yang bekerja meski dengan keterbatasan waktu yang dimilikinya, namun bila ia mampu memanfaatkan dengan maksimal waktu yang dihabiskan bersama anak-anaknya hasilnya jauh akan lebih optimal dibandingkan dengan ibu yang tidak bekerja namun kurang pandai dalam mengelola waktu bersama anak-anaknya. Oleh karena itu setiap ibu baik ia seorang yang bekerja atau tidak bekerja, kemampuan menghabiskan waktu yang berkualitas bersama anak-anaknya menjadi salah satu kemampuan yang wajib dimiliki dan terus dikembangkan (Emmy, 1986).

lbu bekerja mempunyai peran ganda selain sebagai wanita karir juga sebagai ibu rumah tangga. Salah satu dampak negatif dari ibu yang bekerja adalah tidak dapat memberikan perhatian yang penuh pada anaknya ketika anak dalam tahap tumbuh kembang yang pesat. Padahal ibu mempunyai peran penting dalam pengasuhan anak.Oleh karena itu pola asuh yang tepat diperlukan agar anak dapat tumbuh kembang secara optimal (Emmy, 1986)

$$
\text { Hubungan ibu bekerja dengan }
$$

perkembangan balita ada dampak positif dan negatif, dampak positifnya: lbu yang bekerja akan memiliki penghasilan yang dapat menambah pendapatan rumah tangga, para ibu akan lebih memilih membeli sesuatu seperti makanan bergizi berimbang, wanita lebih mampu menentukan banyak pilihan untuk keluarga. Dampak negatif : akibatnya anak mereka akan mengalami gizi kurang mengakibatkan para ibu tidak dapat mengawasi dan ikut berpartisipasi dalam setiap kegiatan anak menurut penelitian Soekirman 1985 dalam Glick 2002. Ibu yang dikategorikan berat dapat mengalami kelelahan fisik, akibatnya tidak dapat mengatur pola makan anak, membiarkan anak-anak mereka makan makanan yang tidak sehat (Fertig et al., 2009), selalu menghabiskan waktu di depan televisi, dan kurang beraktivitas di luar rumah, dapat menyebabkan anak merasa dibuang dan cenderung mencari perhatian di luar rumah (Mehrota, 2011). Untuk itu ibu yang bekerja diluar rumah harus bijaksana mengatur waktu. Bekerja untuk memenuhi kebutuhan keluarga memamg sangat mulia, tetapi tetap harus diingat bahwa tugas utama seorang ibu adalah mengatur rumah tangga. Ibu harus bekerja pagi hari dan pulang pada sore hari tetap harus meluangkan waktu untuk berkomunikasi, bercanda, memeriksa tugas-tugas sekolahnya meskipun ibu capek-capek seteleh seharian bekerja di luar rumah. Pengorbanan tersebut akan menjadi suatu kebahagian jika melihat anak anaknya berkembang menjadi pribadi yang kuat dan stabil http://repository.usu.ac.id/bitstreamwib

Kesimpulan hasil dengan menggunakan uji Chi Square (x2 test) menunjukan adanya nilai probabilitas 0,000 yang berarti lebih kecil dari $\alpha$ $=0,05$. Ketentuan pengujian kalau harga chi quadrat dihitung lebih besar atau sama dengan tabel maka hubungannya signifikan. Dari perhitungan diatas ternyata chi quadrat lebih besar dari pada tabel(10,3> 5,99) dengan dimikian disimpulkan ada hubungan ibu bekerja dengan perkembangan balita usia 4-5 tahun di Desa Grogol Kecamatan Tulangan Kabupaten Sidoarj

Berdasarkan hal tersebut bahwa perhatian dan waktu yang ibu berikan dapat mempengaruhi perkembangan balita karena apabila ibu mengerti, memahami, mendidik dan mengasuh anak dengan baik maka perkembangan anak juga menjadi optimal.

\section{SIMPULAN DAN SARAN}

Dari hasil penelitian dan proses pengolahan data pada tanggal 24-25 Mei 2013 Di Tk Dharma Wanita Desa Grogol Kecamatan Tulangan Kabupaten Sidoarjo, didapatkan beberapa simpulan antara lain : 1.) Sebagian besar responden adalah ibu bekerja; 2.) Perkembangan balita usia 4-5 tahun dengan asuhan ibu yang tidak bekerja di TK Dharma wanita Desa Grogol Kecamatan Tulangan Kabupaten Sidoarjo sebagian besar perkembangannya normal; 3.) Ada hubungan antara ibu bekerja dengan perkembangan balita 
usia 4-5 tahun di Tk Dharma Wanita Desa Grogol Kecamatan Tulangan Kabupaten Sidoarjo.

Saran yang dapat peneliti berikan bagi institusi pendidikan, diharapkan bisa menjalin kerja sama dengan pelayanan kesehatan dalam hal pemberian informasi tentang perkembangan balita. Bagi ibu keluarga dan masyarakat, adalah : 1.) Mendidik anak lebih bijaksana tanpa kekerasan dan tidak terlalu memanjakan; 2.) Memberi sikap atau contoh yang baik kepada anak, memberi perhatian, kasih sayang dan berkomunikasi lebih terbuka. Dan bagi peneliti sendiri adalah lebih meningkatkan dan menambah pengetahuan dan pengalaman yang bermanfaat sehingga memperluas wawasan tentang perkembangan balita usia 4- 5 tahun.

\section{DAFTAR PUSTAKA}

Alimul,A. 2010. Metode Penelitian Kebidanan. Jakarta: Salemba Medika.

Budiono, Eko. http://repository.usu.ac.id/bitstreamwib diakses tanggal 4 maret 2013 jam 19.00 Wib.

Yahyono,Agus.2011. http://irfanyudhistira.wordpress.com diakses tanggal 4 maret 2013 jam 23.00 Wib.

Nurmalisa. 2007 http://bayidananak.com/ Diakses tanggal 3 maret 201319.00 wib

Keswara, KS. 1998. Aspek Kesejahteraan Jiwa Dalam Pembinaan Dan Pengembangan Kesejahteraan Anak Balita. Jakarta: YKAI, FKPPKA.
Maryunami, Anik. 2010. Ilmu Kesehatan Anak Dalam Kebidanan.Jakarta:Trans Info Media.

Nursalim.2012. Asuhan Keperawatan Bayi Dan Anak.Jakarta: Penerbit Salemba Medika.

Notoatmodjo,S. 2010. Metode Penelitian Kesehatan. Jakarta: Rineka Cipta.

Rukiyah, Ai Yeyeh. 2012, Asuhan neonatus.Trans info Media.

Soetjiningsih, 1995.Tumbuh Kembang Anak. Jakarta:EGC

Soesanto Wibisono. 2009. Biostatistik Penelitian Kesehatan. Surabaya: anio. Com

Suherman. 2012. Perkembangan Anak.Jakarta:EGC.

Sugiono. 2012. Statistik Nonparametris. Bandung: Alfabeta

Semium, yusninus. 2010. Asuhan Mental. Jogjakarta: Kanisius

Thobari, M. 2011.Kiat Asyik Pengaruh balita .Yogyakarta: Katahari.

Sugiyono.2010.MetodePenelitianPendidikan.Ba ndung: Alfabeta 